\title{
A Study on Investment Preference and behaviour of Individual Investors in Coimbatore City
}

\author{
K. Parimalakanthi and Dr.M. Ashok Kumar
}

\begin{abstract}
This paper aims to find the behaviour of individual investors of Coimbatore city vis-a-vis available investment avenues in the Indian financial markets. The major factors behind an investment are the safety of principal amount, liquidity, income stability, and appreciation.

A variety of investment avenues are available such as Savings a/c, FD a/c, Government Securities, Corporate Bonds, Insurance policies, Real estates, Commodities, Shares and MFs, Chit Funds and Gold and Silver. All the investors invest their surplus money in the above mentioned avenues depending on their risk taking attitude. "No pain, no gain" it is the golden principle of investment management. In the developing economic one can earn more and more money. 'More risks' lead to more profits. Investors cannot avoid risks but they can minimize the risk by investing their money in various forms of safe investments so that they can get a moderate profit. This study has led the researcher to conclude that most of the investors of Coimbatore city prefer bank deposits followed by investments in gold and silver.
\end{abstract}

Keywords--- Investment behaviour, Investor Information, Investment Avenues, Coimbatore

\section{INTRODUCTION}

$\mathrm{I}^{2}$ $\mathrm{N}$ India financial products for the investors on varying needs and risk appetite are issued. In the past, traditional financial products were offered by the banks (Current Accounts, Saving Banking Accounts, Recurring Deposits, and Fixed Deposits), the Insurance companies, and the Postal Department (Recurring Deposits, National Saving Certificates, KisanVikas Patras). However, in recent years, with the advent of LPG of financial services, the industry has offered diverse financial products such as mutual funds, shares, derivatives, life and non-life insurance schemes (Unit Linked Investment Plans (ULIPs), precious metals such as Gold, Silver as well as provident and pension funds, and children's education plans, etc.). Investment preferences differ from person to person, as each individual behaves differently while investing. Investment behaviour of the individual is influenced by his/her own environment. With an anticipation of creating high returns over a period of time and at certain level of risk, individuals invest in different financial products. Today, a number of investment avenues are available to individuals but an individual, after a thorough study of market and according

K. Parimalakanthi, Ph.D (PT) Research Scholar, Department of Commerce, Karpagam University, Coimbatore-641021

Dr.M. Ashok Kumar, Prof \& Head, Department of Management Studies \& Research, Karpagam University, Coimbatore-641021

DOI: 10.9756/BIJIEMS.8122 to his needs and circumstances, shall have to decide which investment avenue has to be chosen. The present study is an attempt to analyse the investment preferences of individual investors in Coimbatore which is, incidentally, called the "Manchester of South India".

\section{LITERATURE REVIEW}

Narayana (1976) ${ }^{1}$ found that the most important forms of urban financial investment were bank deposits, shares and securities. Mudra - SAMIR'S $(1992)^{2}$ work brings that the fact that the working women in urban India put aside one-fifth of their earnings as savings. According to Jawaharlal, $(1995)^{3}$ investors with be provided with adequate and reliable information so that they can make sound investment decisions. Bandgar P.K (1999) ${ }^{4}$ opines that most of the investors do not know about safety of new issues of company shares, debentures and shares bought stock exchanges. Abhijit Dutta $(2000)^{5}$ observes that the individual investors have high confidence in themselves and are not guided by the market discounted asymmetric information. Maruthupandian.P(2001) ${ }^{6}$ says that investors should remember that their active participation in the activities of the investor forum is a must. The Indian Household Investors Survey, (2004) ${ }^{7}$ registers the fact that a developing economy like India needs a growing amount of household savings to flow to corporate enterprises. Kirshnudu.Ch, B. Krishna Reddy and G. Rama Krishna $\operatorname{Reddy}(2005)^{8}$ have found out that the Investors are mostly influenced by family members while taking decisions on investment. Sridhar.R $(2008)^{9}$ records that the majority of the respondents have invested less than one lakh. SunatanKhurana $(2008)^{10}$ observe that protection is the main purpose for taking an insurance policy. Darshana.P $(2008)^{11}$ the visual and print media and training programs will help investors make wellinformed decisions. Vikram.S $(2008)^{12}$ records that major percentage of respondents have moderate knowledge and have less exposure towards the financial market. Kasilingam.R and Jayabal.G $(2009)^{13}$ observe that the funds invested in small savings schemes will yield good results, not only to individual investors but also to the nation. Selvatharangini P.S (2009) ${ }^{14}$ concludes that generally people differ in their taste and preference. Kaboor.A $(2010)^{15}$ finds that financial literacy is not uniform among different groups of investors. Mathivannan.S and Selvakumar.M $(2011)^{16}$ observe that the teachers are saving their money for the purpose of their children's education, marriage and other welfare expenses. Manish Sitlani, Geeta Sharma \&BhoomiSitlani $(2011)^{17}$ observe that there is no relationship between demographic variables and investment choices of occupants of financial services industry. Suman and Warne.D.P. $(2012)^{18}$ ascertain that the market movements affect the investment patterns of 
investors in the stock market. Alagu Pandian. V and G. Thangadurai $(2013)^{19}$ in their study have found that most of the investors prefer bank deposits followed by investment in gold. Parimalakanthi. K and Dr. M. Ashok kumar $(2015)^{20}$ in their study have found that investors prefer to invest in banks to enjoying the maximum safety. Though various authors have made several studies in the above areas, considering all the observed parameters.

\section{Statement OF THE PRoblem}

The development of any economy depends on healthy savings and proper allocation of capital for the developmental activities of any country. The reduction of disposable income or increase in per-capita income will contribute to savings. The avenues of investment and the investors' opinion based on their preferences vary from person to person. Liquidity and safety play a major role in the investment decision; tax exemption and other factors are also taken into consideration. Apart from the above factors, there are demographic factors which influence the decision on investment. This article discusses the factors which affect the investment behavior of individuals in the city of Coimbatore.

\section{Objective}

To study the investment preference and behaviour of

Table 1: Demographic Profile

\begin{tabular}{|c|c|c|c|c|c|c|c|}
\hline Variables & Particulars & Frequency & $\%$ & Variables & Particulars & Frequency & $\%$ \\
\hline \multirow{2}{*}{ Gender } & Male & 54 & 50.5 & \multirow{5}{*}{ Age } & Below 25 & 25 & 23.4 \\
\hline & Female & 53 & 49.5 & & $26-30$ & 33 & 30.8 \\
\hline \multirow{3}{*}{ Domicile } & Rural & 36 & 33.6 & & $31-35$ & 29 & 27.1 \\
\hline & Urban & 43 & 40.2 & & $36-40$ & 8 & 7.5 \\
\hline & Semi-Urban & 28 & 26.2 & & 41 and above & 12 & 11.2 \\
\hline \multirow{2}{*}{ Type of Residence } & Own & 63 & 58.9 & \multirow{2}{*}{ Marital Status } & Married & 50 & 46.7 \\
\hline & Rented & 44 & 41.1 & & Unmarried & 57 & 53.3 \\
\hline \multirow{4}{*}{ Education } & Up to Schooling & 15 & 14.0 & \multirow{4}{*}{$\begin{array}{c}\text { Family } \\
\text { Size }\end{array}$} & Two & 10 & 9.3 \\
\hline & UG & 30 & 28.0 & & Three & 26 & 24.3 \\
\hline & PG & 30 & 28.0 & & Four & 36 & 33.6 \\
\hline & Professionals & 32 & 29.9 & & More than Four & 35 & 32.7 \\
\hline \multirow{3}{*}{ Earning members } & One & 19 & 17.8 & \multirow{5}{*}{ Occupation } & Agriculture & 16 & 15.0 \\
\hline & Two & 49 & 45.8 & & Business & 20 & 18.7 \\
\hline & More than Two & 39 & 36.4 & & Professional & 39 & 36.4 \\
\hline \multirow{4}{*}{ Wealth } & Affluent & 6 & 5.6 & & Employment-Govt & 14 & 13.1 \\
\hline & Upper Middle Class & 38 & 35.5 & & Employment-Pvt & 18 & 16.8 \\
\hline & Middle Class & 61 & 57.0 & \multirow{2}{*}{ Family Type } & Joint & 33 & 30.8 \\
\hline & Poor & 2 & 1.9 & & Nuclear & 74 & 69.2 \\
\hline
\end{tabular}

From the above table it is inferred that

- Majority of the investors are male

- Most of them reside at the urban area

- Majority of the investors reside at their own house

- Most of the investors have two earning members

- The age of most of the investors ranges between 26 and 30 years

- Majority of the investors are unmarried individual investors in Coimbatore city.

\section{MethodolOGY}

\section{Data}

The data required for the study are primary in nature. The primary data have been collected by making use of a structured questionnaire.

\section{Area of Study}

The present study is confined to the investors of Coimbatore city.

\section{Sample Design}

By adopting convenient sampling, 107 customers have been selected.

\section{Framework of Analysis}

The collected data have been analyzed by making use of Friedman test, Garratt ranking and Factor analysis.

\section{LIMITATION}

The present study covered only Coimbatore city. Hence utmost care is exercised while generalizing the result. 
Table 2: Friedman Test

\begin{tabular}{|l|c|c|}
\hline Source of information & Mean Rank & Rank \\
\hline Print Media - Newspaper & 3.32 & 5 \\
\hline Electronic Media - TV & 3.95 & 2 \\
\hline Internet & 4.59 & 1 \\
\hline Financial Advisors & 3.54 & 4 \\
\hline Friends \& Peer investors & 3.76 & 3 \\
\hline Own analysis & 1.84 & 6 \\
\hline Source : Data Collected and computed through questionnaire \\
\hline
\end{tabular}

The result of Friedman rank test discloses that the majority related information followed by watching television, of investors make use of Internet for mobilizing investment consulting with friends and peer investors, etc.

Table 3: Garrett Ranking

\begin{tabular}{|c|c|c|c|c|c|c|c|c|c|c|c|c|c|c|c|}
\hline \multirow[b]{2}{*}{ S.No } & \multirow[b]{2}{*}{ FACTORS } & \multicolumn{10}{|c|}{ Rank } & \multirow[b]{2}{*}{ 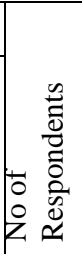 } & \multirow[b]{2}{*}{ 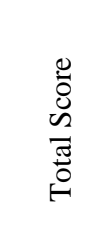 } & \multirow[b]{2}{*}{ 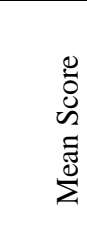 } & \multirow[b]{2}{*}{ 苑 } \\
\hline & & 1 & 2 & 3 & 4 & 5 & 6 & 7 & 8 & 9 & 10 & & & & \\
\hline 1 & Savings a/c in banks & 43 & 43 & 21 & 0 & 0 & 0 & 0 & 0 & 0 & 0 & 107 & 7923 & 74.05 & $\mathrm{I}$ \\
\hline 2 & $\mathrm{FD}$ a/c in banks & 22 & 21 & 43 & 0 & 0 & 21 & 0 & 0 & 0 & 0 & 107 & 7055 & 65.93 & III \\
\hline 3 & Govt Securities & 0 & 0 & 22 & 43 & 21 & 0 & 21 & 0 & 0 & 0 & 107 & 5918 & 55.31 & IV \\
\hline 4 & Corporate Bonds & 0 & 0 & 0 & 0 & 22 & 43 & 21 & 0 & 21 & 0 & 107 & 4763 & 44.51 & VII \\
\hline 5 & Insurance & 0 & 21 & 0 & 0 & 22 & 21 & 22 & 21 & 0 & 0 & 107 & 5388 & 50.36 & VI \\
\hline 6 & Real estates & 0 & 21 & 0 & 0 & 21 & 22 & 43 & 0 & 0 & 0 & 107 & 5509 & 51.49 & $\mathrm{~V}$ \\
\hline 7 & Commodities & 0 & 0 & 0 & 0 & 21 & 0 & 0 & 21 & 22 & 43 & 107 & 3367 & 31.47 & IX \\
\hline 8 & Shares \&MFs & 0 & 0 & 0 & 21 & 0 & 0 & 0 & 65 & 21 & 0 & 107 & 4253 & 39.75 & VIII \\
\hline 9 & Chit Funds & 0 & 0 & 0 & 0 & 0 & 0 & 0 & 0 & 43 & 64 & 107 & 2506 & 23.42 & $\mathrm{X}$ \\
\hline 10 & Gold \& Silver & 42 & 22 & 21 & 22 & 0 & 0 & 0 & 0 & 0 & 0 & 107 & 7626 & 71.27 & II \\
\hline
\end{tabular}

The research of Garrett ranking reveals that respondents prefer to invest in savings a/c followed by Gold and Silver, Fixed deposit $\mathrm{a} / \mathrm{c}$ and the like.

\section{Factor Analysis}

To ascertain the investor attitude before investment, at the time of investment, and post investment, Factor analysis is employed.

Table 4: Factor Analysis

\begin{tabular}{|c|c|c|c|}
\hline FACTORS & 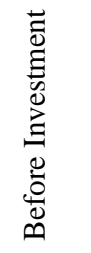 & 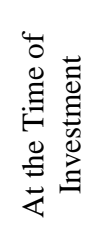 & 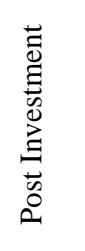 \\
\hline I search for investment options & 0.855 & & \\
\hline I rely on intermediaries for making investments & 0.851 & & \\
\hline I prefer investment based on low transaction cost & 0.829 & & \\
\hline I discuss with my friends, colleagues, family members before I decided on my investments & 0.746 & & \\
\hline My investments are always tenure based & 0.588 & & \\
\hline I watch the performance of investment & & 0.783 & \\
\hline I take responsibility for the investments made & & 0.689 & \\
\hline My choice of investments are be of various avenues & & 0.688 & \\
\hline My investments are diversified & & 0.671 & \\
\hline My investments will be in equal ratio for all avenues & & 0.543 & \\
\hline My investment will be the last resort during contingency & & & 0.801 \\
\hline I make more investments in the same avenue if my objectives are fulfilled & & & 0.799 \\
\hline I analyse my investments and switch to other (s)when I find it appropriate & & & 0.735 \\
\hline I consider using investments for social aspect needs & & & 0.727 \\
\hline I don't consider switching when my investment objectives are met & & & 0.668 \\
\hline
\end{tabular}


All factor loadings are 0.5 and above, showing good convergent validity (Chesney, 2006). The constructs are, therefore, uni-dimensional and factorials distinct, and all items used to operationalize a construct lead on to a single factor which has been grouped into three sets of factors. The result of factor analysis discloses that investors, before making investment, search for various investment options followed by seeking intermediaries' advice and prefer to invest based on transaction cost and the like. At the time of investment the investors ascertains the performance of investments, undertakes the responsibility for their investments, prefers to diversify their investments, etc. Similarly, during the post investment scenario, investors are of the opinion that they will retain their investments till a need arises, wish to make more investments in the same avenue if they receive the expected return from their investments, and agree that they may switch over to other investment sources, when a need arises.

\section{SUGGESTION}

The findings of the study present some implications. The study has a direct bearing on the market for financial products such as Savings a/c in banks, FD a/c in banks, Government Securities, Corporate Bonds, Insurance policies, Real estates, Commodities, Shares \& MFs, Chit Funds and Gold \& Silver. Therefore, it may be of superior interest to policy makers and regulatory authorities concerned with financial market. The regulatory bodies can protect the interests of the new investors on the basis of the pattern of their investing. The following suggestions may be worth considering in this respect:

1. It is suggested to the investors that, instead of keeping a long term investment, their time horizon should depend on their objectives and types of Investment Avenue.

2. Instead of making wrong decisions concerning investment, it is advisable that the investors should take help from the financial planners.

3. Insurance is assurance and not investment. So, it is suggested to the investors that, instead of buying high premium charging policies, they should invest in pure protection plans as the premium is less and the surplus can be capitalized elsewhere and the return can be earned.

4. It has also been suggested that investors are making their investments as the last resort and many a time they are found to have made erroneous investments. So, instead of making the last minute rush investors must plan for their investments from the beginning stage of the financial year.

5. Now-a-days the return on various investments are based on market situation; so, it is advisable that the investors should keep on upgrading themselves with new guidelines and changes in terms and conditions.

6. Not only do they need to know the investment avenues where they have invested, but be aware of the overall investment avenues also. This way they can make necessary changes for keeping their portfolio profitable.

7. SEBI has made changes in the rules for portfolio management service providers and users, as the minimum amount required for Portfolio Management Service is high and fees are also quite higher, as compared to the previous rules. Therefore, it is suggested to the authorities to reframe the rules regarding Portfolio Management Service so that more investors can opt for the service.

8. It is suggested to the investors that at-least the equity portion of their portfolio must be reviewed regularly so that if stock is not performing, then necessary changes can be made.

\section{CONCLUSION}

This research paper shows that education of investors is immensely important for the present day investors in Coimbatore. Investors, before making investments, need to collect investment related information from the internet and consult with friends, peers and investment experts before making investments. The majority of the investors prefer to invest in savings account followed by Gold and Silver, Fixed deposit account and the like. The outcome of the research shows that most of the investors prefer bank deposits followed by investment in gold \& silver investment in the study area.

\section{REFERENCE}

[1] Narayana, D. L. (1976), "Income, Saving and Investment of Household Sector in Chittor District", S.Chand\& Co. Ltd., New Delhi, Pp. 1-187.

[2] Gupta, L.C. (1987), "Shareholders Survey-Geographic Distribution", ICICI and SCMRD, New Delhi.

[3] Mudra-Samir's (1992), survey on “Working women's awareness and attitude toward various saving avenues" Economic Times, 2 September.

[4] JawaharLal (1995), "Personal Investing", Wheeler Publishing, New Delhi.

[5] Bandgar, P.K. (1999), “A Study of Middle Class Investors' Preferences for Financial Instruments in Greater Bombay", Finance India, Vol XIV, No.2, June, 2000, Pp. 574-576

[6] Dutta, Abhijit (2000), "Investors Reaction to Good and Bad News in Secondary Market: A Study Relating to Investor's Behavior", Finance India, Vol. XV, No.2, June 2001, Pp. 567-576.

[7] Maruthupandian.P (2001), "A Study On Equity Investor's Awareness" unpublished thesis, Bharathiyar University, Tamilnadu.

[8] Rajarajan, V. (2003), "Investors Demographics and Risk Bearing Capacity", Finance India, Vol. XVII, No.2, June, Pp.565-576.

[9] Indian Household Investors 2005. The Changing Market Environment Investors. Preferences Problems Policy Issues, Society for Capital Market Research \& Development Delhi.

[10] Ch.Kirshnudu, B. Krishna reddy and G. Rama Krishna reddy (2005), "Investment behavior and risk management".

[11] Sridhar.R (2008). "Investment Practices of Investors in Equity Market".

[12] Sunatankhurana (2008), The ICFAI University Journal of Services Marketing-"Customer Preference in Life Insurance Industry in India", Vol 4, No 3, Pp. 60-68.

[13] Darshana.P (2008) "A Study on Retail Investor's Preference towards Various Investment Avenues".

[14] Vikram.S (2008), "Investor perception and preferences towards stock market investments".

[15] Kasilingam.R\&G.Jayabal (2009), southern economist- "Alternative Investment Option to Small Investors", Vol 48, No 9, September 1, 2009, Pp. 18-20.

[16] Selvatharangini.P.S (2009), "Post Office Savings Schemes in the Maze of Investment Alternatives".

[17] Kaboor.A (2010), "Determinants of investor's financial literacy".

[18] Dr.Mathivannan.S\&Dr.M.selvakumar (2011), Indian Journal of Finance-"Savings and Investment Pattern of School Teachers - A Study with Reference to SivakasiTaluk, Tamil Nadu", Vol 5, No 4, April 2011, Pp.12-26.

[19] Manish Sitlani, Geeta Sharma \& BhoomiSitlani (2011), The IUP Journal of Behavioral Finance-"Investment choice of occupants of financial services industry”, Vol 8, No 1, 2011, Pp. 29-39. 
[20] Suman and Dr. D. P. Warne (February 2012 - Volume 2, Issue 2), "Investment Behaviour of Individual Investor in Stock Market".

[21] V. AlaguPandian and G. Thangadurai "A Study of Investors Preference towards Various Investments Avenues in Dehradun District" (2013) International Journal of Management and Social Sciences Research (IJMSSR) ISSN: 2319-4421Volume 2, No. 4, April 2013

[22] Ms. K. Parimalakanthi and Dr. M. Ashok kumar (2015) "A Study Pertaining to Investment Behaviour of Individual Investors in Coimbatore City" International Journal of Advance Research in Computer Science and Management Studies Volume 3, Issue 6, June 2015, Pp.149-157

[23] Nunnally (1978). http://prr.hec.gov.pk/Chapters/323S-4.pdf 